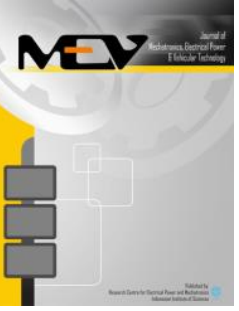

Journal of Mechatronics, Electrical Power, and Vehicular Technology

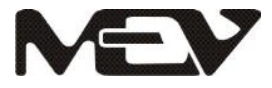

\title{
estimating Power Needed to Fuel Electric Paratransits IN BANDUNG
}

\author{
Naili Huda a, *, Kim P. Hassall ${ }^{\text {b }}$, Aam Muharam a, Kristian Ismail a \\ ${ }^{a}$ Research Centre for Electrical Power and Mechatronics, Indonesian Institute of Sciences \\ Jl. Cisitu/Sangkuriang, Bandung 40135, Indonesia \\ ${ }^{b}$ Department of Infrastructure Engineering, Melbourne School of Engineering \\ Engineering Blocks B, C \& D, The University of Melbourne Parkville 3010 VIC, Australia
}

Received 19 September 2014, received in revised form 17 November 2015, accepted 29 November 2015

Published online 30 December 2015

\begin{abstract}
This is the preliminary finding of a study elaborating the total energy consumption when paratransits in Bandung are altered into electric and the scenario to fulfill it. Therefore, there are lots to be done further concerning result of this initial research, of which will be discussed in another publication. In this paper calculation was done to find out the volume of power needed to fuel electric paratransits in Bandung. Steps carried out include computing total energy consumption for all paratransits, clustering stations from classified routes established by local Department of Transport, and estimating the electricity demand in every clustered station. Data used for this study was acquired from Badan Pusat Statistik Kota Bandung and PT PLN DJA APD Jawa Barat and Banten. A total demand of $61.12 \mathrm{MWh}$ per month will surface to charge the total of 5,521 paratransits from 38 available routes in 15 clustered stations under the assumptions that all paratransits only make 6 return travels per day, operate 30 days per month, and use batteries with 50\% State of Charge.
\end{abstract}

Keywords: transportation; electric paratransit; in town; electricity demand; feasibility study.

\section{INTRODUCTION}

Functioning in a small yet busy city, Bandung transportation is excessively active while on the other hand pollution it produces is too much. These facts make Bandung a potential project site for electric car initiative. Despite its pricey purchase cost [1], electric vehicle (EV) provides solution to lower pollution level and operation as well as maintenance costs reduction [2-5]. Best when applied for mass transport [6] for the sake of more pollution cutback, electric vehicle conversion then could be suitable when implemented to paratransit.

Existing research on Indonesian paratransit mainly discuss about general problems surrounding paratransit [7-9], tariff, service and customer perception $[9,10]$, the effect of air pollution it creates $[11,12]$, driver welfare [1315], routes and programming [16-19], paratransit stop design [20], and feasibility on fleet addition [21]. On Bandung paratransit in particular, main

\footnotetext{
* Corresponding Author.Tel: +62-22-2503055

E-mail: vedderforeva@yahoo.com
}

research were done related to user satisfaction [9, $22,23]$ and feasibility of electric paratransit initiative [24] which emphasizes on cost rather than energy implication.

As the pilot of a more comprehensive research, this paper is limited only to find out total electricity should be made available by the government to guarantee full operation of paratransits when they are converted into electric in Bandung. Conversion could cover retrofitting the available paratransit into electric or procure a full brand new electric vehicle for paratransit. How the demand would be satisfied is beyond the scope of this paper.

\section{Methodology}

This study was done according to simple steps illustrated in Figure 1. With single aim of giving rough estimation of energy demand when paratransits in Bandung turned electric, these following factors are not taken into account in all calculations performed. It has to be born in mind that this study assumes all routes to have the 


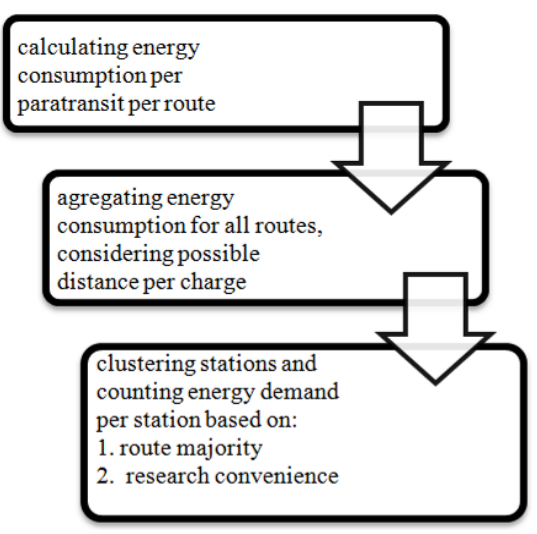

Figure 1. Methodology of this study

same topology, hence using average energy consumption. It is known that topology, traffic, driving style and temperature are of factors affecting energy consumption in EV [25]. In reality, routes topology probably a lot differs, resulting bias from the calculated energy consumption, either too high or even too low. Moreover, it was presumed that electric paratransits are retrofitted into electric using electric motor that still fulfills the function of their old internal combustion engines and fueled using lead acid batteries. Furthermore, regardless distance of each route, all routes are supposed to travel 6 returns per day. Actually, they can travel less and often, more. This will affect the concrete total energy consumption as well. To provide a glimpse of what is paratransit, Figure 2 displays the multicolored paratransits in Bandung whose colors define routes [26].

Using basic retrofitted paratransit in [24], presuming power consumption of retrofitted paratransit would be $500 \mathrm{Wh} / \mathrm{mile}$, lead acid battery energy of 31,680 Wh and battery State of Charge (SoC) of $50 \%$, maximum distance that can be obtained per charge is approximately 51 $\mathrm{km}$. There are 5,521 paratransits available in Bandung, accommodating 38 routes with route distances range from 7 to more than $24 \mathrm{~km}$ one way [27].

For each route, first thing done was calculating kilometer traveled per day for each vehicle, which is 6 returns or equals to 12 times one-way distance. Using 1 mile $=1.61 \mathrm{~km}$, we got energy consumption of $310.56 \mathrm{Wh} / \mathrm{km}$. Considering vehicle load which is about to carry 15 people, this number is in line with other research where a Smart ED of 2 passengers consumes $0.17 \mathrm{Wh} / \mathrm{km}$ [28] and another passenger vehicle consumes an average of 0.62 $\mathrm{MJ} / \mathrm{km}$ [29] or $172.22 \mathrm{Wh} / \mathrm{km}$ when air conditioner is off. By multiplying this energy consumption per kilometer with total distance traveled per day, energy consumption per day per vehicle was found. Multiplying again this number with the quantity of paratransit per route, energy consumption of all paratransits per route per day then is resulted. To find total energy consumption for all paratransit, energy consumptions of all paratransits from all routes were aggregated.

Next step was clustering the avalaible routes to classify paratransits in which route should be charged in which station. Clusters are set in compliance with route and station convenience, and rough observation of paratransit in which route usually be mostly parked in or near which station. Routes, distance of each route, total energy consumption and alternative clustering are recapped in Table 1.

\section{RESULTS AND DISCUSSION}

Total energy needed per day to run all retrofitted paratransits in Bandung is 2,037,397.824 Wh. This makes 61.12 MWh per month. Albeit an official yet confidential data obtained from PT PLN APD Jawa Barat and Banten [30] which seems like a safe supply for the charging needs, it does not mean that charging process can be done anywhere at any time. Mapping should be done in defining which nearest main distributing point can supply the power and at what time slot charging should be done to make sure electricity is sufficiently available, hence preventing blackout. This will be covered in another paper.

As this is a paper that leads to a feasibility study and not analyzing present application, scenario concerning number of paratransits involved in this electrification project can actually later be extrapolated. This is critical to define which number will match Bandung capability in providing electricity to support eparatransits. Extrapolation can be executed concerning degree of electrification covering which routes should be involved, number of altered paratransits per route, work hours, number of travels and State of Charge (SoC).

Lessening routes number will decrease the power demand. From road topology point of view, this would be wise if implemented to routes that have hilly road topology. Hilly road calls for higher energy consumption than estimated, hence higher energy demand. For shorter routes $(10 \mathrm{~km}$ and below), e-paratransit application would be convenience as charging can be done after 2-time returns. Cutting the number of paratransits to be converted to electric will cut the total energy consumption as well. Not to mention reducing the number of work hour and travels per day. In contrast, lowering or increasing SoC will not have significant effect to total energy consumption. To charging process, the action 
Table 1.

Total energy consumption and proposed stations clustering
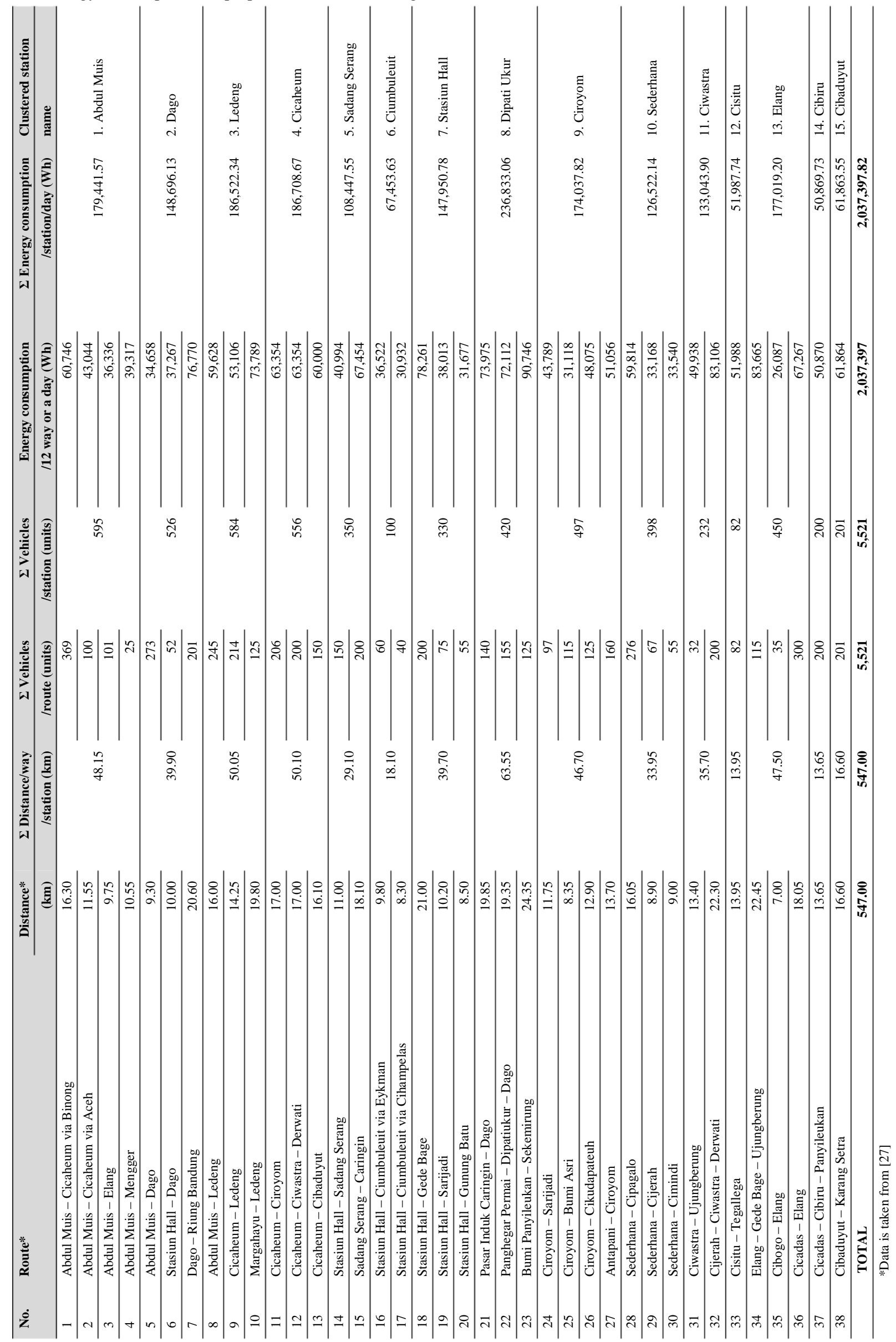


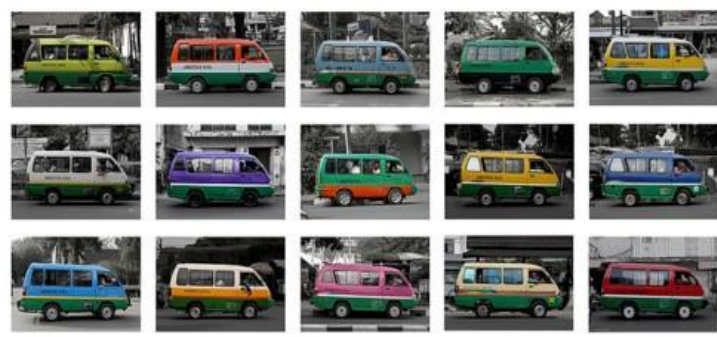

Figure 2. Paratransit colors interpret its specific route [26]

will only affect charging schedule since the charging should be done earlier and shorter (when SoC is smaller) or later and longer (when $\mathrm{SoC}$ is bigger).

From 38 routes, it was created 15 charging stations based on rough observation of majority paratransit settled on the stations when not in operation, and distance of paratransit parking and owner dwellings. Table 1 lists all that proposed charging locations. Actually, this kind of clustering might not be effective since there will be lots of efforts to put it into realization. The problem is when not in use paratransits are usually parked within the close proximity of the owners, which are often located far from the stations. Therefore, if paratransits are charged in the stations, then to be brought home to the owners, the energy reserved for the next run the day after will be lessened. There are two proposed ways to overcome this. First, build a station where people can park their paratransit as well as charge them. Even though this is one manifestation of government interference, the cost would be massive, for building and security officer for instance. Or instead, conduct a survey to map locations of each paratransit park lot, and subsequently create new locations for charging station and its new capacity as oppose from the old charging stations clustered above. This can be solved by providing a battery exchange, a big wide warehouse where batteries are charged to be readily used later.

This is just a convenience clustering that actually needs to be further investigated. The ideal should incorporate detail process comprising mapping paratransit parking locations, mapping electricity supply at potential or designated charging hours, matching number of charging needs with charging supply, and last but not least, interviewing stakeholders.

As transportation is the main contributor for air pollution in Bandung [31], and shifting to environmentally safe fuel and vehicle can be the way out [32] [33], paratransit electrification could be the answer to Bandung's circumstances. Beside, global condition creates a more conducive movement for electric vehicle application [34].
In accordance to fund in creating start-up fleet, government should do its best to establish a funding policy for this matter [2]. Be it the government, private sectors or other possible third parties. As considering cost to procure one electric paratransit could reach IDR 500 million, or IDR 450 million via retrofitting [24], sum of money should be provided would be huge. This cost falls mostly for batteries, which need to be replaced approximately once a year when lead acid is used. This cost will decline due to mass electrification since for example, battery price will decrease from bulk buy [3, 35]. Nevertheless, it still involved so much money. Further discussion about this is not within the reach of this paper.

Another option of charging stations is battery exchange or battery swapping stations. When battery is low, paratransit could visit a battery exchange station to have its empty battery be replaced with the fully loaded one. Nonetheless, as the consequence, a big warehouse containing stacks of battery should be provided. This will bring new obligations like land acquisition, building construction, operational management and security. Since the two alternatives in really have their own advantages and disadvantages, both can be executed according to circumstances of the future charging station locations.

\section{Conclusion}

Paratransit electrification in Bandung yields a power demand of virtually $62 \mathrm{MWh}$ per month that should be met by energy provider, which in this case is Indonesian Government through PLN (name of Indonesian national electricity company). Even the demand seems can be sufficiently fulfilled, careful planning should be conducted to ensure the demand will be satisfied without disturbing other industry. The planning will embrace obtaining real data on energy demand for paratransit electrification in Bandung. Field survey would be crucial in acquiring data to design and map places of charging stations taken into account paratransit parking and electricity availability at certain charging hours.

\section{ACKNOWLEDGEMENT}

Gratitude goes to Sunarto Kaleg, M. Redho Kurnia, and Abdul Hapid for the useful discussion on EV retrofitting; Arifin Nur, Yanuandri Putrasari, Achmad Praptijanto, Widodo Budi Santoso and Bambang Wahono on the potential of electric paratransit in Bandung; Pudji Irasari and Amin on data collection, and finally, to Fitri Rahma from PLN Jawa Barat for providing electricity supply data. 


\section{REFERENCES}

[1] A. Kihm and S. Trommer, "The new car market for electric vehicles and the potential for fuel substitution," Energy Policy, vol. 73, pp. 147-157, 10// 2014.

[2] E. H. Green et al., "Increasing electric vehicle policy efficiency and effectiveness by reducing mainstream market bias," Energy Policy, vol. 65, pp. 562-566, 2// 2014.

[3] T. Muneer et al., "Energetic, environmental and economic performance of electric vehicles: Experimental evaluation," Transportation Research Part D: Transport and Environment, vol. 35, pp. 40-61, 3// 2015.

[4] Z. A. Needell, "Technology evaluation for automobile transportation: electric vehicle energy requirements under real-world use," in Electric vehicle energy requirements under real-world use, ed, 2015.

[5] I. Wolf et al., "Changing minds about electric cars: An empirically grounded agent-based modeling approach," Technological Forecasting and Social Change, vol. 94, pp. 269-285, 5// 2015.

[6] P. A. Driscoll et al., "Is the future of mobility electric? Learning from contested storylines of sustainable mobility in Iceland," European Planning Studies, vol. 20, pp. 627-639, 2012.

[7] I. Syabri and B. T. S. Pradono, "Embracing paratransit in Bandung Metropolitan Area, West Java, Indonesia," 2011.

[8] O. Z. Tamin, "Integrated public and road transport network system for Bandung metropolitan area (Indonesia)," Proc. Eastern Asia Soc. Transport. Studies, vol. 5, pp. 1281-1300, 2005.

[9] T. B. Joewono et al., "Paratransit transport in Indonesia: Characteristics and user perceptions," presented at the Eastern Asia Society for Transportation Studies 2015 Conference, Cebu Philipines, 2015.

[10] Y. O. Susilo et al., "An exploration of public transport users' Attitudes and preferences towards various policies in Indonesia: Some preliminary results," Journal of the Eastern Asia Society for Transportation Studies, vol. 8, pp. 299-314, 2009.

[11] H. Anggraini and E. T. Maharani, "Paparan Timbal $(\mathrm{Pb})$ pada rambut sopir angkot rute Johar-Kedungmundu," Media Kesehatan Masyarakat Indonesia, vol. 11, pp. 47-50, 2012.
[12] D. Condrorini et al., "Gender aspects in public perception and acceptance of angkot stopping point as an effort to reduce roadside air pollution (Case study of angkot in Bandung, Indonesia)," in Proceedings: International Conference on Air Quality Management in Southeast Asia, 2007, p. 239.

[13] C. Nisa, "Respon Pengemudi Jasa Transportasi Angkutan Umum Kota (Angkot) Kota Bogor Terhadap Kenaikan Harga BBM Jenis Premium," 2012.

[14] A. D. Rahayu, "Model matematika pendapatan pengemudi angkutan kota (angkot) jalur ADL dan AL di Malang," 2011.

[15] W. Weningtyas et al., "Does Improved level of paratransit service improve drivers' quality of life?," Journal of the Eastern Asia Society for Transportation Studies, vol. 10, pp. 1367-1383, 2013.

[16] F. Arthuro, "Aplikasi mobile rute angkot Kota Bekasi dengan sistem operasi Android 2.3. 3 menggunakan Adt Bundle dan Sqlite," 2013.

[17] M. Irawan, "Penerapan algoritme Dijkstra pada rute angkot Bogor berbasis Android," 2013.

[18] O. F. Saputra and H. B. E. Prakoso, "Kajian pelayanan rute moda angkutan kota (angkot) di Kota Cimahi," Universitas Gadjah Mada, 2014.

[19] E. S. Wihidayat, "Sistem informasi transportasi umum terpadu dengan sistem informasi geografis (SIG) berbasis web, Studi kasus angkutan umum Kota Bandung," Universitas Gadjah Mada, 2013.

[20] F. R. Aulia and D. Wahjudi, "Pengembangan fasilitas transpotasi publik dengan desain halte dan rambu lalu lintas khusus pada halte di Kota Bandung," Product Design, vol. 3, 2014.

[21] M. S. Bahkri, "Analisa kelayakan investasi penambahan armada angkot (Studi kasus: Perusahaan Kopasri Jurusan PilangsariPasar Bunder Sragen)," Universitas Muhammadiyah Surakarta, 2011.

[22] A. Tarigan et al., "Negative experiences and willingness to use paratransit in Bandung, Indonesia: An exploration with ordered probit model," Center for Transport and Society, vol. 15, p. 16, 2010.

[23] A. K. Tarigan et al., "Segmentation of paratransit users based on service quality and travel behaviour in Bandung, Indonesia," Transportation planning and technology, vol. 37, pp. 200-218, 2014. 
[24] N. Huda, "Viability of lead acid battery conversion for electric paratransit initiative in Bandung Indonesia " Master of Engineering Science, Civil Engineering, The University of Melbourne, Melbourne, 2009.

[25] C. De Cauwer et al., "Energy consumption prediction for electric vehicles based on real-world data," Energies (19961073), vol. 8, pp. 8573-8593, 2015.

[26] -, "Direktori Info Bandung," vol. 2015, ed, 2013.

[27] Badan Pusat Statistik Kota Bandung, "Bandung City in Figures," Bandung2014.

[28] T. Donateo et al., "A method to estimate the environmental impact of an electric city car during six months of testing in an Italian city," Journal of Power Sources, vol. 270, pp. 487-498, 2014.

[29] D. A. Howey et al., "Comparative measurements of the energy consumption of 51 electric, hybrid and internal combustion engine vehicles," Transportation Research Part D: Transport and Environment, vol. 16, pp. 459-464, 2011.

[30] P. P. A. Jawa Barat dan Banten, "Beban Tertinggi 1 Oktober - 31 Oktober 2015," ed. Bandung, 2015.
[31] N. Ambarsari et al., "Inventarisasi emisi black carbon, prekursor ozon $(\mathrm{CO}, \mathrm{NOx}$, spesi VOC) dan penentuan ozone formation potential (Studi Kasus: Bandung raya) emission inventory of black carbon, ozone precursors (CO, NOx, VOC species) and Quantifying Of."

[32] N. Kusminingrum and G. Gunawan, "Polusi udara akibat aktivitas kendaraan bermotor di jalan perkotaan Pulau Jawa dan Bali," Jurnal, Jakarta, Puslitbang Jalan dan Jembatan, 2008.

[33] H. Ma et al., "A new comparison between the life cycle greenhouse gas emissions of battery electric vehicles and internal combustion vehicles," Energy Policy, vol. 44, pp. 160-173, 2012.

[34] B. A. Davis and M. A. Figliozzi, "A methodology to evaluate the competitiveness of electric delivery trucks," Transportation Research Part E: Logistics and Transportation Review, vol. 49, pp. 823, 2013.

[35] P. D. Larson et al., "Consumer attitudes about electric cars: Pricing analysis and policy implications," Transportation Research Part A: Policy and Practice, vol. 69, pp. 299-314, 11// 2014. 